\title{
JNVEST[GHACJÓN
}

\section{Evaluation of the anti-inflammatory and anti-arthritic effects of some plant extracts}

\author{
By N.M. Abdel-Moein, ${ }^{1}$ E.A. Abdel-Moniem, ${ }^{1 *}$ D.A. Mohamed $^{2}$ and E.A. Hanfy ${ }^{1}$
}

\author{
${ }^{1}$ Biochemistry Department, Faculty of Agriculture, Cairo University, Cairo, Egypt. \\ ${ }^{2}$ Food Sciences and Nutrition Department, National Research Centre, Dokki, Cairo, Egypt \\ ( ${ }^{\star}$ Corresponding author: dohamohamed@yahoo.com)
}

\section{RESUMEN}

\section{Evaluación de los efectos anti-inflamatorio y anti- artrítico de algunos extractos de plantas}

El objetivo de la presente investigación ha sido estudiar la actividad anti-inflamatoria de flores de albahaca dulces, hojas de eucalipto, hojas de apio y salvia. Se ha estudiado el efecto sobre la inflamación aguda de extractos metanólicos de apio, salvia y eucalipto y sobre la artritis inducida en ratas. Se han evaluado los efectos de los extractos metanólicos de apio, salvia y eucalipto sobre los parámetros bioquímicos determinados en la artritis inducida y su seguridad en las funciones del hígado y el riñón. Se han estudiado los ácidos grasos, hidrocarburos y fitoesteroles de todas las plantas objeto de la investigación. Los resultados han revelado una actividad antiinflamatoria de los extractos de las plantas estudiadas con diferentes grados entre un 47 y un $62 \%$. Los extractos metanólico de apio, de salvia y de eucalipto han mostrado una mejoría de los niveles de malondialdehído en plasma, factor de necrosis tumoral $\alpha$ y de ácido úrico, también se muestra una mejoría significativa en el peso corporal y en la ingesta total de alimentos. Los extractos metanólicos de apio, de salvia y de eucalipto han mostrado una total seguridad sobre la función hepática y renal. Los ácidos $\alpha$-linolénico y linoleico estaban presentes en todas las plantas estudiadas así como los esteroles Estigmasterol y $\beta$-sitosterol.

PALABRAS CLAVE: Albahaca - Anti-inflamatorio - Antiartrítico - Apio - Eucalipto - Salvia.

\section{SUMMARY}

Evaluation of the anti-inflammatory and anti-arthritic effects of some plant extracts

The objective of the present research was to study the anti-inflammatory activity of sweet basil flowers, leaves of eucalyptus and the aerial parts of celery and sage on acute inflammation along with the effect of a methanol extract of celery, sage and eucalyptus on adjuvant induced arthritis in rats. The effect of the methanol extract of celery, sage and eucalyptus on certain biochemical parameters in adjuvant arthritis and its safety in liver and kidney functions were evaluated. The fatty acids, hydrocarbons and phytosterols of all plants under investigation were studied. The results revealed a marked anti-inflammatory activity of all the studied plant extracts with different degrees ranging from 47 to $62 \%$. The methanol extract of celery, sage and eucalyptus showed improvement in the level of plasma malondialdehyde, tumor necrosis factor- $\alpha$ and uric acid and also showed significant improvements in body weight and total food intake. The methanol extract of celery, sage and eucalyptus showed complete safety for liver and kidney functions. $\alpha$-Linolenic acid and linoleic acid were present in all the studied plants. Stigmasterol and $\beta$-sitosterol were present in all the studied plants.

KEY-WORDS: Anti-arthritic - Anti-inflammatory - Celery - Eucalyptus sage - Sweet basil.

\section{INTRODUCTION}

Rheumatoid arthritis (RA) is one of the major human autoimmune diseases affecting about 1 per cent of the adult population (Lipsky, 2005). The disease is characterized by inflammation of the synovial tissue and damage to the cartilage and bone of the joints, leading to severe deformities (Brennan \& Mclnnes, 2008; Gorman \& Cope, 2008). The drugs that inhibit inflammatory reactions are a vital component of the therapeutic arsenal against RA (Kremers et al., 2004). However, the adverse reactions and toxicity associated with the use of these drugs have expeditiously promoted the use of natural plant products or procedures belonging to the diverse traditional systems of medicine by patients with RA (Nozaki et al., 2006; Chang et al., 2010) and other chronic inflammatory disorders (Salvioli et al., 2007; Jung et al., 2007; Alleva et al., 2010). This growing trend warrants a continuous search for new natural anti-arthritic products. Adjuvant-induced arthritis (AIA) is a wellestablished model of rheumatoid arthritis that can be induced in rats by an intradermal injection of Freund's adjuvant (Holmdahl et al., 2001). The AIA model reproduces most of the bone changes found in RA (Holmdahl et al., 2001), including inflammatory bone loss, which has been linked to an increased risk of fracture (Joffe \& Epstein, 1991). The role of plant products in various diseases has been known 
from ancient times. Various groups have shown the beneficial effects of vegetables, fruits, tea, etc., as these foods contain flavonoids and other polyphenolic compounds which have been reported to have multiple biological effects including antiinflammatory action, inhibition of platelet aggregation, antimicrobial activity and antitumor activities (Prior, 2003). The objective of the present research was to study the anti-inflammatory activity of sweet basil flowers, the aerial parts of celery and sage and the leaves of eucalyptus on acute inflammation using the carrageenan model of inflammation and a methanol extract of celery, sage and eucalyptus on rheumatoid arthritis using adjuvant induced arthritis in rats. The aim also included studying the effect of the methanol extract of celery, sage and eucalyptus on certain biochemical parameters in adjuvant arthritis. The safety of the methanol extract of celery, sage and eucalyptus was evaluated through the determination of liver and kidney functions. The aim also included studying the fatty acids and unsaponifiable matter of all plants under investigation.

\section{MATERIALS AND METHODS}

\subsection{Materials}

\section{Plant samples}

The flowers of sweet basil (Ocimum basilicum L., Family Labiataceae,) the aerial parts of celery (Apium graveolens, Family Umbelliferae) and sage (Salvia officinalis Family Labiataceae) and the leaves of eucalyptus (Eucalyptus globules, Family Myrtaceae) were obtained from the Experimental Station of Medicinal Plants, Faculty of Pharmacy, Cairo University, Giza.

\section{Chemicals}

$\lambda$-Carrageenan, type IV (Sigma, USA): Onepercent carrageenan suspension was prepared freshly for the induction of acute inflammation. Freund's complete adjuvant (Sigma, USA) was used for the induction of adjuvant arthritis in rats.

\section{Animals}

Male Sprague Dawley rats $120-150 \mathrm{~g}$ were used in this study. The animals were kept individually in stainless steel cages at room temperature of $25 \pm$ $2^{\circ} \mathrm{C}$ and a relative humidity of about $55 \%$; water and food were given ad-libtium.

\section{Diets}

A balanced diet composed of $10 \%$ protein supplemented from casein, $10 \%$ corn oil, $23.5 \%$ sucrose, $47 \%$ maize starch, $5 \%$ fiber, $3.5 \%$ salt mixture (Briggs and Williams, 1963) and 1\% vitamin mixture (Morcos, 1967) was prepared for feeding rats throughout the experimental period.

\subsection{Methods}

\section{Preparation of plant materials}

The fresh flowers of sweet basil, the aerial parts of celery and sage and the leaves of eucalyptus were washed with tap water. All plant materials were dried separately in an air-circulated oven at $40^{\circ} \mathrm{C}$ to complete dryness and then reduced to powder form.

\section{Preparation of plant extracts}

The dried powder of different plants was separately placed in a continuous extraction apparatus (Soxhelt) and subjected to successive extraction using petroleum ether $\left(40-60^{\circ} \mathrm{C}\right)$ followed by methanol. The solvent of each extract was removed by evaporation under reduced pressure. All extracts were kept in vacuum dessicators over anhydrous calcium chloride. The essential oil of sweet basil was extracted using isolation by hydrodistillation (200-300 g of plant per sample) for $6 \mathrm{~h}$ using a Clevenger-type apparatus according to the European Pharmacopoeia (Conseil de l'Europe, 1996).

\section{Assessment of fatty acids, hydrocarbons and phytosterols contents in plant extracts}

The hydrocarbon and phytosterol fraction and fatty acid methyl esters of the studied extracts were prepared according to A.O.A.C (2000) to be subjected to a GLC analysis of fatty acids, hydrocarbons and phytosterols.

The hydrocarbon and phytosterol fraction was analyzed by GLC adopting the following conditions: Column: 10\% OV-101 packed column; Stationary phase: Chromosorb W-HP; Detector temperature: $290^{\circ} \mathrm{C}$; Injector temperature, $28^{\circ} \mathrm{C}$; Carrier gas $\mathrm{N}_{2}$; flow-rate $30 \mathrm{ml} / \mathrm{min}$; air flow-rate: $300 \mathrm{ml} / \mathrm{min} ; \mathrm{H}_{2}$ Flow-rate $30 \mathrm{ml} / \mathrm{min}$; Detector FID; Chart speed: $0.5 \mathrm{~cm} / \mathrm{min}$; Oven program: Initial temperature, $70^{\circ} \mathrm{C}$; Final temperature, $270^{\circ} \mathrm{C}$; programmed $4^{\circ} \mathrm{C} / \mathrm{min}$. For $35 \mathrm{~min}$ at $270^{\circ} \mathrm{C}$, total time, $85 \mathrm{~min}$. The identification of hydrocarbons and the sterol contents of the unsaponifiable matter was carried out by comparison of their retention times with co-injected authentic reference compounds. Quantification was based on peak area integration.

The analysis by GLC of the methyl ester was carried out according to the following conditions: Stationary phase: $10 \%$ diethylene glycosuccinate (DEGS) packed column; oven temperature, $170^{\circ} \mathrm{C}$; detector temperature, $300^{\circ} \mathrm{C}$; injector temperature, $250^{\circ} \mathrm{C}$; Carrier gas, $\mathrm{N}_{2}$; flow-rate, $30 \mathrm{ml} / \mathrm{min}$; air flow-rate, $350 \mathrm{ml} / \mathrm{min} ; \mathrm{H}_{2}$ flow-rate, $350 \mathrm{ml} / \mathrm{min}$; 
detector, FID; Chart speed, $2 \mathrm{~cm} / \mathrm{min}$. Identification of the fatty acid methyl ester was carried out by direct comparison of the retention times of each of the separated compounds with authentic samples of the fatty acid methyl esters analyzed under the same conditions. Quantification was based on peak area integration.

\section{Preparation of dosage form}

A methanol and petroleum ether extract of the aerial parts of celery and sage, leaves of eucalyptus, sweet basil flowers and the essential oil of sweet basil were emulsified separately in water using gum acacia as emulsifying agent.

\section{Design of experimental work}

The work was divided into two stages.

\section{First stage: Induction of acute inflammation in rats.}

Sixty rats were divided into ten groups, each group containing 6 rats. Prior to treatment, the volume of the paw of each animal was determined using vernier calipers. Eight groups were given one oral dose of $500 \mathrm{mg}$ of methanol or petroleum ether extracts of sweet basil, celery, eucalyptus and sage $/ \mathrm{kg}$ rat body weight. The ninth group of rats was given one oral dose of essential oil of sweet basil (500 mg/kg rat body weight). A control group received a $0.9 \% \mathrm{NaCl}$ solution, under the same experimental conditions (Lanher et al., 1992). One hour after these administrations, each rat received a subplantar injection of $1 \%$ carrageenan suspension $(0.1 \mathrm{ml}$ per animal) in its left hind paw. Then the thickness of the paw (foot) of each rat was measured at 1, 2, 3 and 4 hours after the injection of the inflammatory agent. The thickness of inflammation was calculated by subtracting the foot thickness before inflammation from that of the inflamed foot at the different time intervals.

\section{Second stage: Induction of rheumatoid arthritis in rats using adjuvant induced arthritis (Anti-arthritic effect).}

Thirty rats were divided into 5 groups, each comprised of six rats. Three test groups were given daily oral doses of $500 \mathrm{mg}$ of methanol extract of the aerial parts of celery, leaves of sage and eucalyptus/kg rat body weight. The other two groups served as control (one group as normal control and the second as arthritic control). A day after starting medication, arthritis was induced in all rats (except one of the control groups which is the normal group) by subcutaneous injection of Freund's complete adjuvant into the subplantar region of the right hind paw (Singh et al., 1992). All the oral medication continued for 14 days. The rats were maintained on the balanced diet throughout the experiment. Paw thickness were measured before the induction of arthritis and at the end of the experimental period using vernier calipers. At the end of experiment, the increase in the thickness of the injected foot of the rats of the test groups was compared with that of the arthritic control rats. During the experiment, body weight and food intake was recorded. At the end of the experiment, total food intake, body weight gain and food efficiency were calculated. After the experimental period, the rats fasted for 16 hours and blood samples were taken from the eye vein orbital of the anaesthetized rats. Plasma were separated for the determination of plasma uric acid (Watts, 1974), plasma tumor necrosis factor- $\alpha$ (TNF- $\alpha$ ) (an inflammatory biomarker) (Stepaniak et al., 1995) and malondialdehyde (MDA) as indicators of lipid peroxidation (Satoh, 1978). The safety of plant extracts was studied through the evaluation of liver and kidney functions. The plasma levels of creatinine (Houot, 1985) and urea (Fawcett \& Scott, 1960) were determined as indicators of kidney function, while the activity of aspartate transaminase (AST), alanine transaminase (ALT) (Reitman and Frankel, 1957) and alkaline phosphatase (ALP) (Belfield and Goldberg, 1971) were determined as indicators of liver function. The animal experiments were conducted according to the Medical Research Ethics Committee, National Research Center, Cairo, Egypt. To deduce the thickness of inflammation in the rats of each group, the thickness of the foot at the start of the experiment was subtracted from that at the end of the experiment.

\section{Statistical analysis}

The results of the animal experiments were expressed as Mean \pm SE and they were analyzed statistically using the one-way analysis of variance ANOVA followed by Duncan's test.

\section{RESULTS}

Tables (1) and (2) show the fatty acid,hydrocarbon and phytosterol fractions in the studied plants. The results of fatty acid analysis reveal that $\alpha$-linolenic acid ( $\omega-3$ fatty acid) was present in all the studied plants. The sweet basil flowers showed the highest content of $\alpha$-linolenic acid, while the sage aerial parts showed the lowest content. All the studied plants contain linoleic acid ( $\omega-6$ fatty acid). Palmitic acid was the major saturated fatty acid in celery aerial parts. Octanoic acid was the major saturated fatty acid in sage aerial parts and sweet basil flowers, while lauric acid was the major saturated fatty acid in eucalyptus leaves. $\gamma$-Linolenic acid was present in all the studied plants except the celery aerial parts. The sage aerial parts showed the highest content of saturated fatty acids, while basil sweet flowers showed the highest content of unsaturated fatty acids. The GLC investigation of the hydrocarbon and phytosterol fraction revealed the presence of stigmasterol and $\beta$-sitosterol in all 
Table 1

Fatty acids contents of the different plants under study (as percentage of total fatty acids)

\begin{tabular}{lcccc}
\hline \multicolumn{1}{c}{ Fatty acids } & Celery aerial parts & Sage aerial parts & Sweet basil flowers & Eucalyptus leaves \\
\hline Caprylic (C8:0) & 13.4 & 30.4 & 7.7 & 3.8 \\
Capric (C10:0) & 4.8 & 15.8 & 1.2 & 20.5 \\
Lauric (C12:0) & 4.0 & 21.7 & 3.0 & 29.6 \\
Myristic (C14:0) & 4.2 & - & 3.4 & - \\
Palmitic (C16:0) & 19.3 & 18.1 & 0.37 & 19.2 \\
Palmitoleic (C16:1) & 2.2 & 3.2 & 4.2 & 10.1 \\
Stearic (C18:0) & 0.4 & 0.52 & 0.86 & - \\
Oleic (C18:1) & 2.5 & 0.86 & 17.9 & - \\
Linoleic (C18:2) & 22.6 & 6.6 & 5.8 & 7.0 \\
$\alpha$-Linolenic (C18:3) & 6.7 & 1.0 & 34.3 & 8.7 \\
$\gamma$-Linolenic (C18:3) & - & 0.98 & 0.40 & 0.98 \\
Arachidic (C20:0) & 1.5 & 0.78 & 0.85 & - \\
Gondoic (C20:1) & 18.4 & - & 20.0 & - \\
Total saturated fatty acids & $\mathbf{4 7 . 6 0}$ & $\mathbf{8 7 . 3 0}$ & $\mathbf{1 7 . 3 8}$ & $\mathbf{8 2 . 6 0}$ \\
Total unsaturated fatty acids & $\mathbf{5 2 . 4 0}$ & $\mathbf{1 2 . 6 4}$ & & $\mathbf{7 3 . 1 0}$ \\
\hline
\end{tabular}

Table 2

GLC analysis of hydrocarbons and phytosterols of the different plants under study (as percentage of total hydrocarbons and phytosterols)

\begin{tabular}{|c|c|c|c|c|}
\hline Hydrocarbon \& phytosterols & $\begin{array}{c}\text { Celery aerial } \\
\text { parts }\end{array}$ & $\begin{array}{c}\text { Sage aerial } \\
\text { parts }\end{array}$ & $\begin{array}{l}\text { Sweet basil } \\
\text { flowers }\end{array}$ & $\begin{array}{c}\text { Eucalyptus } \\
\text { leaves }\end{array}$ \\
\hline \multicolumn{5}{|l|}{ Hydrocarbon: } \\
\hline $\mathrm{C} 14$ & 1.6 & 8.6 & - & - \\
\hline C16 & 3.7 & 17.4 & - & 0.18 \\
\hline $\mathrm{C} 17$ & 5.9 & - & - & - \\
\hline C18 & 6.7 & 1.5 & 8.4 & 0.59 \\
\hline C19 & - & 9.1 & 11.0 & 3.1 \\
\hline $\mathrm{C} 20$ & - & 9.7 & 3.7 & 11.1 \\
\hline $\mathrm{C} 21$ & 0.6 & 1.1 & 1.2 & 1.2 \\
\hline $\mathrm{C} 22$ & 0.8 & 1.8 & 34.4 & 2.4 \\
\hline $\mathrm{C} 24$ & 54.7 & 18.8 & 0.7 & 34.9 \\
\hline $\mathrm{C} 25$ & 3.0 & 2.5 & 4.3 & 4.3 \\
\hline $\mathrm{C} 26$ & 0.9 & 5.7 & 6.2 & 6.3 \\
\hline $\mathrm{C} 27$ & 1.5 & 1.0 & 3.0 & 3.7 \\
\hline $\mathrm{C} 28$ & 12.0 & 3.8 & 3.6 & 6.5 \\
\hline $\mathrm{C} 29$ & 1.3 & - & - & - \\
\hline C31 & - & - & 4.1 & - \\
\hline C32 & - & 4.5 & - & 2.0 \\
\hline Total hydrocarbon & 92.7 & 85.5 & 80.6 & 76.3 \\
\hline \multicolumn{5}{|l|}{ Phytosterols: } \\
\hline Stigmasterol & 5.6 & 11.4 & 6.4 & 11.1 \\
\hline$\beta$-Sitosterol & 1.7 & 3.1 & 11 & 4.1 \\
\hline Total phytosterols & 7.3 & 14.5 & 17.4 & 15.2 \\
\hline
\end{tabular}


the studied plants. Stigmasterol was of the highest percentage in the sage aerial parts and eucalyptus leaves, while $\beta$-sitosterol was the major phytosterol in sweet basil flowers. Sweet basil flowers showed the highest content of total phytosterols, while celery aerial parts contain the lowest.

The results of the acute inflammation test are shown in Tables 3 and 4 . In the control animals, the sub plantar injection of carrageenan produced inflammation in the following hour, which increased progressively to reach a maximum intensity 3 or 4 hours after the injection of carrageenan. Pretreatment with different plant extracts significantly reduced the carrageenan-induced edema. All extracts showed inhibition of inflammation in the first hour from carrageenan injection. The inhibition of inflammation was significant throughout the whole experimental period (4 hours). The methanol and petroleum ether extracts of sage showed the highest reduction of inflammation in the fourth hour after carrageenan injection (57\% and $66 \%$, respectively). The methanol extract of eucalyptus showed the maximum inhibition of inflammation in the first hour after carrageenan injection. The present results indicate that the studied extracts exhibit anti-inflammatory effects on the acute inflammatory process (carrageenan induced edema in rat paw). The petroleum ether extract of the sage aerial parts was the most promising followed by its methanol extract, while the methanol extract of sweet basil flowers was the least efficient anti-inflammatory agent.

\section{Inflammation thickness of arthritic rats.}

The increase in foot thickness (Thickness of inflammation) of the control arthritic rats at the end of the experiment compared with that of rats given the different treatments are presented in Table (5). Oral administration of plant extracts suppressed the swelling in the foot significantly. Significant changes were observed between arthritic rats given the extract of eucalyptus or sage compared with the celery extract. All extracts produced reductions in inflammation ranging from 47 to $62 \%$. Sage and eucalyptus extracts showed the same inhibition activity of $62 \%$, while the celery extract showed $47 \%$ inhibition of the inflammation volume.

\section{Biochemical and nutritional parameters of arthritic rats}

The results of the biochemical changes in arthritic rats given the different treatments are shown in Table (6). The plasma levels of uric acid, MDA and TNF- $\alpha$ were significantly higher in arthritic control rats than in the normal control. The plasma level of TNF- $\alpha$ as an indicator of inflammatory markers decreased significantly in arthritic rats given different plant extracts compared to the arthritic control but still significantly higher than the normal control. Administration of different methanol extracts showed a significant reduction in the plasma levels of uric acid and MDA (indicator of lipid peroxidation) with different degrees when compared with the arthritic control but still significantly higher than the normal control.

Plasma levels of creatinine and urea as indicators of kidney function showed non-significant changes in all groups (Table 7). Also, the plasma activity of AST, ALT and ALP as indicators of liver function showed non-significant changes in all the studied groups. This revealed the complete safety of the studied extracts (Table 7).

Table 3

Mean thickness of hind paw $(\mathrm{mm})$ induced in different experimental groups by carrageenan

\begin{tabular}{|c|c|c|c|c|c|}
\hline \multirow{2}{*}{ Groups } & \multicolumn{5}{|c|}{ Time (hours) } \\
\hline & 0 & 1 & 2 & 3 & 4 \\
\hline Control & $0.35^{b} \pm 0.0$ & $0.54^{a} \pm 0.008$ & $0.60^{a} \pm 0.02$ & $0.64^{a} \pm 0.02$ & $0.72^{a} \pm 0.02$ \\
\hline \multicolumn{6}{|l|}{ Methanol extract } \\
\hline Sage & $0.35^{b} \pm 0.0$ & $0.45^{d} \pm 0.02$ & $0.46^{c} \pm 0.02$ & $0.49^{e} \pm 0.02$ & $0.51^{\text {ef }} \pm 0.02$ \\
\hline Celery & $0.35^{b} \pm 0.0$ & $0.46^{c d} \pm 0.02$ & $0.49^{b c} \pm 0.01$ & $0.53^{\text {ed }} \pm 0.01$ & $0.55^{\text {cde }} \pm 0.01$ \\
\hline Eucalyptus & $0.37^{\mathrm{ab}} \pm 0.01$ & $0.45^{d} \pm 0.01$ & $0.48^{b c} \pm 0.01$ & $0.52^{\text {de }} \pm 0.01$ & $0.54^{\text {de }} \pm 0.02$ \\
\hline Sweet basil & $0.38^{\mathrm{a}} \pm 0.01$ & $0.50^{\mathrm{abc}} \pm 0.02$ & $0.57^{\mathrm{a}} \pm 0.02$ & $0.59^{b c} \pm 0.02$ & $0.59^{b c} \pm 0.01$ \\
\hline \multicolumn{6}{|c|}{ Petroleum ether extract } \\
\hline Sage & $0.37^{a b} \pm 0.01$ & $0.53^{a b} \pm 0.01$ & $0.50^{b c} \pm 0.01$ & $0.49^{e} \pm 0.01$ & $0.49^{\dagger} \pm 0.01$ \\
\hline Celery & $0.36^{\mathrm{ab}} \pm 0.01$ & $0.48^{\mathrm{cd}} \pm 0.01$ & $0.49^{\mathrm{bc}-} \pm 0.01$ & $0.55^{c d} \pm 0.01$ & $0.55^{\text {cde }} \pm 0.01$ \\
\hline Eucalyptus & $0.37^{\mathrm{ab}} \pm 0.01$ & $0.53^{a b} \pm 0.01$ & $0.51^{b} \pm 0.001$ & $0.55^{c d} \pm 0.02$ & $0.55^{\text {cde }} \pm 0.02$ \\
\hline Sweet basil & $0.37^{\mathrm{ab}} \pm 0.01$ & $0.53^{a} \pm 0.01$ & $0.57^{a} \pm 0.01$ & $0.63^{a b} \pm 0.02$ & $0.63^{b} \pm 0.02$ \\
\hline \multicolumn{6}{|l|}{ Essential oil } \\
\hline Sweet basil & $0.36^{a b} \pm 0.08$ & $0.48^{\mathrm{bcd}} 0.02$ & $0.56^{\mathrm{a}} \pm 0.02$ & $0.58^{b c} \pm 0.02$ & $0.58^{b c d} \pm 0.02$ \\
\hline
\end{tabular}

The data are expressed as mean values \pm standard error.

In each column the same letter means non significant difference, while different letters mean significant difference at 0.05 probability. 
Table 4

The mean anti-inflammation activity of different plant extracts under study.

\begin{tabular}{|c|c|c|c|c|}
\hline \multirow{2}{*}{ Groups } & \multicolumn{4}{|c|}{ Time (hours) } \\
\hline & 1 & 2 & 3 & 4 \\
\hline Control & $0.20^{a} \pm 0.01$ & $0.24^{a} \pm 0.02$ & $0.30^{a} \pm 0.02$ & $0.37^{a} \pm 0.02$ \\
\hline \multicolumn{5}{|l|}{ Methanol extract } \\
\hline Sage & $0.10^{d} \pm 0.02$ & $0.11^{\mathrm{bc}} \pm 0.02$ & $0.14^{\mathrm{bc}} \pm 0.02$ & $0.16^{\mathrm{bcd}} \pm 0.02$ \\
\hline Inhibition \% & 48 & 55 & 51 & 57 \\
\hline Celery & $0.11^{c d} \pm 0.02$ & $0.14^{\mathrm{cd}} \pm 0.01$ & $0.18^{\text {cde }} \pm 0.01$ & $0.2^{\mathrm{cd}} \pm 0.01$ \\
\hline Inhibition \% & 43 & 41 & 40 & 45 \\
\hline Eucalyptus & $0.08^{d} \pm 0.02$ & $0.12^{d} \pm 0.02$ & $0.15^{\mathrm{de}} \pm 0.01$ & $0.18^{\text {cde }} \pm 0.02$ \\
\hline Inhibition \% & 57 & 52 & 49 & 52 \\
\hline Sweet basil & $0.12^{\text {bcd }} \pm 0.02$ & $0.18^{b c} \pm 0.02$ & $0.21^{b c} \pm 0.02$ & $0.21^{b c d} \pm 0.01$ \\
\hline Inhibition \% & 40 & 25 & 27 & 43 \\
\hline \multicolumn{5}{|c|}{ Petroleum ether extract } \\
\hline Sage & $0.16^{\mathrm{abc}} \pm 0.02$ & $0.13^{c d} \pm 0.02$ & $0.13^{\mathrm{e}} \pm 0.01$ & $0.13^{\mathrm{e}} \pm 0.01$ \\
\hline Inhibition \% & 19 & 45 & 57 & 66 \\
\hline Celery & $0.12^{\mathrm{bcd}} \pm 0.02$ & $0.13^{c d} \pm 0.01$ & $0.2^{c d} \pm 0.01$ & $0.2^{c d} \pm 0.01$ \\
\hline Inhibition \% & 39 & 45 & 34 & 48 \\
\hline Eucalyptus & $0.16^{\mathrm{ac}} \pm 0.02$ & $0.15^{b c d} \pm 0.2$ & $0.18^{\mathrm{cd}} \pm 0.03$ & $0.18^{c d} \pm 0.03$ \\
\hline Inhibition \% & 19 & 38 & 37 & 50 \\
\hline Sweet basil & $0.17^{\mathrm{ab}} \pm 0.01$ & $0.20^{a b} \pm 0.01$ & $0.26^{\mathrm{ab}} \pm 0.3$ & $0.26^{b} \pm 0.03$ \\
\hline Inhibition \% & 15 & 18 & 13 & 30 \\
\hline \multicolumn{5}{|l|}{ Essential oil } \\
\hline Sweet basil & $0.13^{\mathrm{bcd}} \pm 0.017$ & $0.20^{\mathrm{ab}} \pm 0.02$ & $0.23^{b c} \pm 0.02$ & $0.23^{b c} \pm 0.02$ \\
\hline Inhibition \% & 36 & 15 & 23 & 39 \\
\hline
\end{tabular}

The data are expressed as mean values \pm standard error.

In each column the same letter means non significant difference, while different letters mean significant difference at 0.05 probability.

The results of the nutritional parameters are shown in Table (8). Body weight gain, total food intake and food efficiency ratio decreased significantly in the control rats with adjuvant arthritis and the arthritic rats given oral administration of the different extracts compared to the normal control. Oral administration of the different extracts showed significant improvement in body weight gain with different degrees compared with the arthritic control. This improvement may be attributed to the improvement in food intake.

\section{DISCUSSION}

Many animal models of acute inflammation have been developed for the discovery and evaluation of new anti-inflammatory agents. The studied plant extracts showed significant antiinflammatory activity with different degrees in the carrageenan model of acute inflammation in rats. The edema which develops in rat paws after carrageenan injection is mediated by histamine and S-hydroxytryptamine during the first hour, after which the increased vascular permeability is maintained by a kinin release for up to 2.5 hours. From 2.5-6.0 hours, the inflammatory mediator is prostaglandin [especially $\mathrm{PGE}_{2}$ ] (due to the induction of COX-2) which coincides with the enhanced thromboxanes $\mathrm{B}_{2}$ (DiRosa \& Willoughby, 1971; Selibert et al., 1994). So, the mechanism of action of the studied extracts as anti-inflammatory involved a reduction of all the aforementioned inflammatory mediators since the inhibition of inflammation occurred throughout the time intervals of the experiment. The onset of inflammation symptoms and increased prostaglandin production usually correspond with cyclooxygenase 2 (COX2). COX-2 is not detectable in normal tissue, but is detectable after introducing a pro-inflammatory agent (van Ryn et al., 2000).

Chronic inflammation is a prominent feature of many joint diseases, including rheumatoid arthritis (de Grauw et al., 2009). Adjuvant-induced arthritis is an animal model of chronic inflammation 
Table 5

The increase in thickness of injected foot (after 13 days) of adjuvant arthritis induction of arthritic rats given a daily oral dose $(500 \mathrm{mg} / \mathrm{kg}$ rat body weight) of methanol extracts of plants under study

\begin{tabular}{llc}
\hline \multicolumn{1}{c}{ Groups } & Mean \pm SEM & \% Inhibition of inflammation \\
\hline Arthritic control & $0.38^{\mathrm{a}} \pm 0.02$ & - \\
Celery & $0.20^{\mathrm{b}} \pm 0.03$ & 47 \\
Eucalyptus & $0.14^{\mathrm{c}} \pm 0.01$ & 62 \\
Sage & $0.14^{\mathrm{c}} \pm 0.01$ & 62 \\
\hline
\end{tabular}

In each column the same letter means non significant difference, while different letters mean significant difference at 0.05 probability.

Table 6

Effect of methanol extract of sage, eucalyptus and celery on the levels of plasma MDA, TNF- $\alpha$ and uric acid of normal and arthritic rats

\begin{tabular}{lccc}
\hline \multicolumn{1}{c}{ Groups } & $\begin{array}{c}\text { MDA } \\
(\mathbf{n m o l} / \mathbf{m l})\end{array}$ & $\begin{array}{c}\text { Uric acid } \\
(\mathbf{m g} / \mathbf{d l})\end{array}$ & $\begin{array}{c}\text { TNF- } \alpha \\
(\mathbf{p g} / \mathrm{ml})\end{array}$ \\
\hline Normal & $3.3^{\mathrm{b}} \pm 0.25$ & $1.9^{\mathrm{c}} \pm 0.27$ & $18.9^{\mathrm{d}} \pm 0.58$ \\
Arthritic control & $6.9^{\mathrm{a}} \pm 0.81$ & $3.4^{\mathrm{a}} \pm 0.21$ & $30.7^{\mathrm{a}} \pm 0.78$ \\
Celery methanol extract & $4.9^{\mathrm{b}} \pm 0.33$ & $2.7^{\mathrm{ab}} \pm 0.20$ & $26.2^{\mathrm{b}} \pm 0.56$ \\
Sage methanol extract & $3.9^{\mathrm{b}} \pm 0.56$ & $2.2^{\mathrm{bc}} \pm 0.23$ & $22.5^{\mathrm{c}} \pm 0.59$ \\
Eucalyptus methanol extract & $3.0^{\mathrm{b}} \pm 0.17$ & $2.5^{\mathrm{bc}} \pm 0.21$ & $23.5^{\mathrm{c}} \pm 0.62$ \\
\hline
\end{tabular}

In each column the same letter means non significant difference while different letters mean significant difference at 0.05 probability.

The data are expressed as mean values \pm standard error.

Table 7

Effect of different methanol extracts on liver and kidney functions of rats

\begin{tabular}{lccccc}
\hline \multicolumn{1}{c}{ Groups } & $\begin{array}{c}\text { AST } \\
(\mathrm{U} / \mathrm{ml})\end{array}$ & $\begin{array}{c}\text { ALT } \\
(\mathrm{U} / \mathrm{ml})\end{array}$ & $\begin{array}{c}\text { ALP } \\
(\mathbf{I U} / \mathrm{L})\end{array}$ & $\begin{array}{c}\text { Urea } \\
(\mathrm{mg} / \mathrm{dl})\end{array}$ & $\begin{array}{c}\text { Creatinine } \\
(\mathbf{m g} / \mathrm{dl})\end{array}$ \\
\hline Normal Control & $25.0^{\mathrm{a}} \pm 0.86$ & $29.5^{\mathrm{a}} \pm 1.24$ & $79.7^{\mathrm{a}} \pm 5.28$ & $46.2^{\mathrm{a}} \pm 3.03$ & $0.6^{\mathrm{a}} \pm 0.12$ \\
Arthritic control & $25.1^{\mathrm{a}} \pm 0.80$ & $28.3^{\mathrm{a}} \pm 1.18$ & $81.9^{\mathrm{a}} \pm 7.10$ & $38.9^{\mathrm{a}} \pm 4.32$ & $1.0^{\mathrm{a}} \pm 0.29$ \\
Sage methanol extract & $26.8^{\mathrm{a}} \pm 0.76$ & $28.2^{\mathrm{a}} \pm 0.89$ & $75.0^{\mathrm{ab}} \pm 8.76$ & $41.1^{\mathrm{a}} \pm 3.95$ & $0.8^{\mathrm{a}} \pm 0.13$ \\
Eucalyptus methanol & $28.3^{\mathrm{a}} \pm 0.71$ & $28.7^{\mathrm{a}} \pm 1.03$ & $68.3^{\mathrm{ab}} \pm 9.00$ & $34.9^{\mathrm{a}} \pm 2.02$ & $0.9^{\mathrm{a}} \pm 0.40$ \\
extract & $26.6^{\mathrm{a}} \pm 1.28$ & $26.8^{\mathrm{a}} \pm 0.59$ & $55.1^{\mathrm{b}} \pm 4.03$ & $37.6^{\mathrm{b}} \pm 3.81$ & $1.0^{\mathrm{a}} \pm 0.18$ \\
Celery methanol extract & &
\end{tabular}

In each column the same letter means non significant difference while different letters mean significant difference at 0.05 probability.

The data are expressed as mean values \pm standard error.

which is similar to rheumatoid arthritis in humans. It can be induced in rats by an intradermal injection of Freund's adjuvant. Adjuvant arthritis is characterized by inflammation, high oxidative stress and reduction in body weight (Ibáñez de Cáceres et al., 2000). The induction of chronic inflammation in rats in the present work was reflected in the increased inflammatory biomarkers. TNF- $\alpha$ was the biomarker of inflammation assessed in the present study and showed extreme elevation in the control adjuvant arthritic rats compared to the normal control. This result was in agreement with the work of Glenn \& Kooyers (1966) and Mahajan et al. (2007). The elevation in the plasma levels of MDA in the arthritic control rats in the current research is in agreement with the results of Tastekin et al. (2007). The administration of methanol extract of sage, celery and eucalyptus to arthritic rats produced significant improvement in inflammatory and lipid peroxidation biomarkers together with a reduction in inflammation thickness. Serum urate has powerful antioxidant properties. At concentrations normally occurring in human plasma, urate directly scavenges the hydroxyl radical, singlet oxygen and peroxyl radicals from lipid peroxidation (Heffner and Repine, 1989). Additionally, uric acid prevents the oxidation of vitamin C (Sevenian et al., 1985). The results showed significant increases in plasma uric acid in arthritic rats when compared with the normal control. Oral administration of different 
Table 8

Nutritional parameters of different experimental groups (Mean \pm SE)

\begin{tabular}{lccccc}
\hline \multicolumn{1}{c}{ Groups } & $\begin{array}{c}\text { Initial body } \\
\text { weight } \\
\mathbf{( g )}\end{array}$ & $\begin{array}{c}\text { Final } \\
\text { body weight } \\
\mathbf{( g )}\end{array}$ & $\begin{array}{c}\text { Body weight } \\
\text { Gain } \\
\mathbf{( g )}\end{array}$ & $\begin{array}{c}\text { Total food } \\
\text { intake } \\
(\mathbf{g})\end{array}$ & $\begin{array}{c}\text { Food } \\
\text { efficiency } \\
\text { ratio }\end{array}$ \\
\hline Normal control & $151.2^{\mathrm{a}} \pm 1.9$ & $191^{\mathrm{a}} \pm 2.7$ & $39.8^{\mathrm{a}} \pm 1.6$ & $211.5^{\mathrm{a}} \pm 3.0$ & $0.19^{\mathrm{a}} \pm 0.01$ \\
Arthritic control & $151.0^{\mathrm{a}} \pm 1.5$ & $170.3^{\mathrm{d}} \pm 1.8$ & $19.3^{\mathrm{d}} \pm 1.2$ & $164.3^{\mathrm{d}} \pm 5.9$ & $0.12^{\mathrm{d}} \pm 0.00$ \\
Celery methanol extract & $1.51 .3^{\mathrm{a}} \pm 2.8$ & $186.5^{\mathrm{ab}} \pm 2.7$ & $35.2^{\mathrm{b}} \pm 0.9$ & $207.0^{\mathrm{ab}} \pm 3.3$ & $0.17^{\mathrm{b}} \pm 0.00$ \\
Eucalyptus methanol extract & $151.3^{\mathrm{a}} \pm 1.6$ & $182.5^{\mathrm{bc}} \pm 1.5$ & $31.2^{\mathrm{c}} \pm 1.0$ & $199.7^{\mathrm{c}} \pm 1.6$ & $0.16^{\mathrm{c}} \pm 0.01$ \\
Sage methanol extract & $151.2^{\mathrm{a}} \pm 2.1$ & $178.8^{\mathrm{c}} \pm 2.0$ & $27.7^{\mathrm{c}} \pm 1.3$ & $190.0^{\mathrm{bc}} \pm 4.0$ & $0.15^{\mathrm{c}} \pm 0.00$ \\
\hline
\end{tabular}

In each column the same letter means non significant difference while different letters mean significant difference at 0.05 probability.

extracts reduced urate levels as a result of reducing oxidative stress.

The anti-inflammatory effect of the studied plants may be attributed to the presence of long chain fatty acids, phytosterols and phenolic compounds.

Long chain fatty acids have been reported to have antidenaturant activity, which might have beneficial effects in rheumatic diseases. These fatty acids possess significant anti-inflammatory activity (Saso et al., 1999). Polyunsaturated fatty acids, especially $\alpha$-linolenic acid $(\omega-3)$, were present in all the studied plants. Polyunsaturated fatty acids of the $\omega-3$ series are essential for normal growth and development. The health effects of these fatty acids include a reduction in cardiovascular risk due to antiarrhythmic, anti-inflammatory, anti-thrombotic and lipid lowering actions (Martain et al., 2009). Ingestion of $\omega-3$ fatty acids decreases membrane arachidonic acid and concomitantly decreases the capacity to synthesize eicosanoids from the arachidonic; eicosapentaenoic acid gives rise to the 3-series prostaglandins and thromboxans and the 5-series leukotrienes (Calder, 1998). Diets containing $\omega-3$ fatty acids are beneficial in decreasing the levels of certain pro-inflammatory chemokines thereby delaying the onset of and severity of autoimmune symptoms (Venkatraman \& Meksawan, 2002). Alphalinolenic acid can be converted to eicosapentaenoic acid, which competitively inhibits the oxygenation of arachidonic acid by cyclooxygenase. In addition, eicosapentaenoic acid is able to act as a substrate for both cyclooxygenase and 5-lipoxygenase leading to inhibition of the inflammatory mediator prostaglandin $\mathrm{E}_{2}$ and leukotriene $\mathrm{B}_{4}$ (Calder \& Yaqoob, 2009).

Phytosterols are important structural components of plant membranes and they play a key role in plant cell membrane function (Dillard \& German, 2000). The present results show the presence of $\beta$-sitosterol and stigmasterol in the unsaponifiable fraction of the studied plants. $\beta$-sitosterol, its glycoside and stigmasterol have been reported to have antiinflammatory and immune-modulating activities (Gomez et al., 1999; Bouic \& Lamprecht, 1999). Plant sterols display their anti-inflammatory activity through inhibition of the secretion of interleukin- 6 and tumor necrosis factor- $\alpha$ (Bouic, 2001). Phytosterols have been shown to possess antioxidant and antiinflammatory activities (Mohamed et al., 2005).

Phenolic compounds play an important role in the protection of humans from damage by free radicals through its antioxidant activity (Löliger,1991). Phenolic compounds also have been reported to possess anti-inflammatory activity (Löliger, 1991). Celery contains $\beta$-carotene, lutein and the flavones, luteolin and apigenin (Lugasi et al., 2003). López-Lázaro (2009) has shown that luteolin possesses a variety of pharmacological activities, including antioxidant and anti-inflammatory activities. Different celery leaf extracts are scavengers of $\mathrm{OH}^{\circ}$ and $\mathrm{DPHH}^{\circ}$ radicals and reduce liposomal peroxidation, which points to their antioxidant activity. The antioxidant activity of celery leaf extracts may be due to the presence of flavonoids (Popovic et al., 2006). Recently, petroleum ether and methanol extracts of both celery leaves and seeds showed anti-gout activity in gouty rats (Mohamed and Al-Okbi, 2008). The anti-gout, antiinflammatory and antioxidant activity of celery extracts may be due to the presence of phenolic compounds, long chain fatty acids and phytosterols as reported by Mohamed and Al-Okbi (2008). Sweet basil contains rosmarinic acid, which possesses anti-inflammatory and antioxidant activities (Makino et al., 2000; Jayasinghe et al., 2003). Sage leaf aqueous and butanol extracts have analgesic and anti-inflammatory effects due to the presence of carnosol and carnosic acid, which are phenolic diterpenes (Qnais et al., 2010; Kim et al., 2010).

The decrease in body weight gain and food efficiency ratio in the control arthritic rats compared to the normal control was expected since it has been reported that rheumatoid arthritis is usually associated with loss of lean tissues, which contain most of the body's protein (Bistrian \& Blackburn, 1983). The decrease in body weight gain in the arthritic control rats may be due to tissue destruction in adjuvant arthritic rats. The rates of proteasemediated degradation of muscle protein were accelerated without changes in protein synthesis in experimental arthritis (Fagan et al., 1987). When intracellular proteolysis of muscle proteins by lysosomal proteases is mediated by $\mathrm{PGE}_{2}$ the later increased during inflammation (Fagan et al., 1987). 
Also, the reduction in body weight gain may be due to muscle wasting in experimental arthritis, which seems to be due to enhanced protein breakdown by the ubiquitin-proteasome proteolytic pathway (Lecker et al., 2004; Granado et al., 2005). It was noticed that food intake was also reduced significantly, which may share in the reduction of body weight gain. It has also been reported that rheumatoid arthritis is associated with anorexia (Bistrian \& Blackburn, 1983). It was noticed that all treatments produced significant increases in body weight gain and food efficiency ratio. The significant improvement in body weight gain in arthritic rats is an indicator of improvement in adjuvant arthritis (Glenn \& Kooyers, 1966).

In conclusion, the methanol and petroleum ether extracts of celery, sage, eucalyptus and sweet basil and the essential oil of sweet basil can be used as anti-inflammatory agents in acute inflammation. The methanol extract of celery, sage, eucalyptus and sweet basil can be safely used as anti-arthritic natural products. The anti-inflammatory effect may be attributed to the presence of polyunsaturated fatty acids, phytosterols and phenolic compounds.

\section{REFERENCES}

Alleva LM, Cai C, Clark I.A. 2010. Using complementary and alternative medicines to target the host response during severe influenza. Evidence-Based Complementary and Alternative Medicine. 7, 501-510.

A.O.A.C. 2000. Official Methods of Analysis (17 $7^{\text {th }}$ ed.). (Association of Official Agricultural Chemists, Gaithersburg, MD).

Belfield A, Goldberg DM. 1971. Revised assay for serum phenyl phosphate activity using 4-amino-antipyrine. Enzyme 12, 561-573.

Bistrian BR, Blackburn GL. 1983. Assessment of proteincalorie malnutrition in the hospitalized patient. In: Nutritional Support of Medical Practice. (eds. H.A. Schneider, C.E. Anderson, D.B. Coursin) Harper and Row, New York, 128-153.

Bouic PJ. 2001. The role of phytosterols and phytosterolins in immune modulation: a review of the past 10 years. Curr. Opin. Clin. Nutr. Metab. Care. 4, 471-475.

Bouic PJ, Lamprecht JH. 1999. Plant sterols and sterolins: a review of their immune-modulating properties. Altern. Med. Rev. 4, 170-7.

Brennan FM, McInnes IB. 2008. Evidence that cytokines play a role in rheumatoid arthritis. Journal of Clinical Investigation 118, 3537-3545.

Briggs GM, Williams MA. 1963. A new mineral mixture for experimental rat diets and evaluation of other mineral mixtures. Fed. Proc. 22, 261-266.

Calder PC. 1998. Dietary fatty acids and the immune system. Nutr. Rev. 56, S70-S83.

Calder PC, Yaqoob P. 2009. Understanding omega-3 polyunsaturated fatty acids. Postgrad Med. 121, 148-57.

Chang JM, Cheng CM, Hung LM, Chung YS, Wu RY. 2010. Potential use of plectranthus amboinicus in the treatment of rheumatoid arthritis. Evidence-Based Complementary and Alternative Medicine. 7, 115-120.

Conseil de l'Europe: Pharmacopée Européenne. France: Maisonneuve S.A.: Sainte Ruffine 1996.

De Grauw JC, van de Lest CH, van Weeren PR. 2009. Inflammatory mediators and cartilage biomarkers in synovial fluid after a single inflammatory insult: a longitudinal experimental study. Arthritis Res. Ther. 11, R35.

Dillard CJ, German JB. 2000. Phytochemicals and human health. J. Sci. Food Agric. 80, 1744-1756.

DiRosa M, Willoughby DA. 1971. Screens for antiinflammatory drugs. J. Pharm. Pharmac. 23, 297-298.

Fagan JM, Waxman L, Goldberg AL. 1987. Skeletal muscle and liver contain a soluble ATP + ubiqutin-dependent protedytic system. Biochem. J. 243, 335-340.

Fawcett JK, Scott JE. 1960. A rapid and precise method for the determination of urea. J. Clin. Pathol. 13, 156159.

Glenn EM, Kooyers WM. 1966. Plasma inflammation units: An objective method for investigating effects of drugs on experimental inflammation. Life Sci. 5, 619-628.

Gómez MA, Sáenz MT, García MD, Fernández MA. 1999. Study of the topical anti-inflammatory activity of Achillea ageratum on chronic and acute inflammation models. Z. Naturforsch [C]. 54, 937-941.

Gorman CL, Cope AP. 2008. Immune-mediated pathways in chronic inflammatory arthritis. Best Practice and Research: Clinical Rheumatology 22, 221-238.

Granado M, Priego T, Martín Al, Villanúa MA., LópezCalderón A. 2005. Ghrelin receptor agonist GHRP-2 prevents arthritis-induced increase in E3 ubiquitinligating enzymes MuRF1 and MAFbx gene expression in skeletal muscle. American Journal of Physiology, Endocrinology and Metabolism 289, E1007-E1014.

Heffner JE, Repine JE. 1989. Pulmonary strategies of antioxidant defence. Am. Rev. Respir. Dis. 140, 531.

Holmdahl R, Lorentzen JC, Lu S, Olofsson P, Wester L, Holmberg J, Pettersson U. 2001. Arthritis induced in rats with nonimmunogenic adjuvants as models for rheumatoid arthritis. Immunol. Rev. 184, 184-202.

Houot O. 1985. Interpretation of clinical laboratory tests. Edit. Siest G, Henny J, Schiele F, Young D S. Biomedical publications.

Ibáñez de Cáceres I, Villanúa M, Soto L, Martín Al, López-Calderón A. 2000. Insulin like growth factor (IGF-I) and IGF-binding proteins in rats with adjuvantinduced arthritis given recombinant human growth hormone. J. Endocrinol 165, 537-544.

Jayasinghe C, Gotoh N, Aoki T, Wada S. 2003. Phenolics composition and antioxidant activity of sweet basil (Ocimum basilicum L.). J. Agric. Food Chem. 51, 4442-9.

Joffe I, Epstein S. 1991. Osteoporosis associated with rheumatoid arthritis: pathogenesis and management. Semin Arthritis Rheum. 20, 256-272.

Jung SM, Schumacher HR, Kim H, Kim M, Lee SH, Pessler F. 2007. Reduction of urate crystal-induced inflammation by root extracts from traditional oriental medicinal plants: elevation of prostaglandin D2 levels. Arthritis Research and Therapy. 9, R64.

Kim SY, Park E, Park JA, Choi BS, Kim S, Jeong G, Kim CS, Kim do K, Kim SJ, Chun HS. 2010. The plant phenolic diterpene carnosol suppresses sodium nitroprusside-induced toxicity in c6 glial cells. J. Agric. Food Chem. 58, 1543-50.

Kremers HM, Nicola P, Crowson CS, O'Fallon WM, Gabriel SE. 2004. Therapeutic strategies in rheumatoid arthritis over a 40-year period. Journal of Rheumatology 31, 2366-2373.

Lanhers CM, Fleurentin J, Mortier F, Vinche A, Younos C. 1992. Anti-inflammatory and analgesic effects of aqueous extract of Harpagophtum procumbens. Planta Med. 58, 117.

Lecker SH, JagoeRT, Gilbert A,GomesM,BaracosV, Bailey J, Price SR, Mitch WE, Goldberg AL. 2004. Multiple types 
of skeletalmuscle atrophy involve a common program of changes in gene expression. FASEB Journal 18, 39-51.

Lipsky P. E. 2005. "Rheumatoid arthritis," in Harrison's Principles of Internal Medicine, D. Kasper, E. Braunwald, A. Fauci, S. Hauser, D. Longo, and J. Jameson, Eds., pp. 1968-1977, McGraw-Hill, New York, NY, USA, 16th edition.

Löliger J. 1991. The use of antioxidants in food. In Free radicals and food additives. Aruoma, OI.; Halliwell, B. Eds. Taylor and Francis, London, pp. 129- 138.

López-Lázaro M. 2009. Distribution and biological activities of the flavonoid luteolin. Mini Rev. Med. Chem. 9, 31-59.

Lugasi A, Hòvári J, Sági KV, Birò L. 2003. The role of antioxidant phytonutrients in the prevention of diseases. Acta Biologica Szegediensis 47, 119-125.

Mahajan SG, Mali RG, Mehta AA. 2007. Protective Effect of Ethanolic Extract of Seeds of Moringa oleifera Lam. against Inflammation Associated with Development of Arthritis in Rats. J. Immunotoxicol 4, 39-47.

Makino T, Ono T, Muso E, Yoshida H, Honda G, Sasayama S. 2000. Inhibitory effects of rosmarinic acid on the proliferation of cultured murine mesangial cells. Nephrol Dial Transplant 15, 1140-5.

Martín de Santa Olalla L, Sánchez Muniz FJ, Vaquero MP. 2009. N-3 fatty acids in glucose metabolism and insulin sensitivity. Nutr. Hosp. 24, 113-27.

Mohamed DA, Ismael Al, Ibrahim AR. 2005. Studying the anti-inflammatory and biochemical effects of wheat germ oil. Deutsche Lebensmittel-Rundschau 101, 66-72.

Mohamed DA, Al-Okbi SY. 2008. Evaluation of anti-gout activity of some plant foods. Pol. J. Food Nutr. Sci. 58, 389-395.

Morcos SR. 1967 The effect of protein value of the diet on the neurological manifestations produced in rats by $\beta$-immodipropionitrile. Br. J. Nutr. 21, 269-274.

Nozaki K, Hikiami H, Goto H, Nakagawa T, Shibahara N, Shimada Y. 2006. Keishibukuryogan (GuiZhi-Fu-Ling-Wan), a Kampo formula, decreases disease activity and soluble vascular adhesion molecule-1 in patients with rheumatoid arthritis. Evidence-Based Complementary and Alternative Medicine 3, 359-364.

Popovic M, Kaurinovic B, Trivic S, Mimica-Dukic N, Burac M. 2006. Effect of celery (Apium graveolens) extracts on some biochemical parameters of oxidative stress in mice treated with carbon tetrachloride. Phytother Res. 20, 531-7.

Prior RL. 2003. Fruits and vegetables in the prevention of cellular oxidative damage. Am. J. Clin. Nutr. 78, 570S-578S.
Qnais EY, Abu-Dieyeh M, Abdulla FA, Abdalla SS. 2010. The antinociceptive and anti-inflammatory effects of Salvia officinalis leaf aqueous and butanol extracts. Pharm. Biol. 48, 1149-56.

Reitman S, Frankel S. 1957 Colorimetric methods for aspartate and alanine aminotransferase. Am. J. Clin. Path. 28, 55-60.

Saso L, Valentini G, Casini ML, Mattei E, Braghiroli L, Mazzanti G, Panzironi C, Grippa E, Silvestrini B. 1999. Inhibition of protein denatruation by fatty acids, bile salts and other natural substances: a new hypothesis for the mechanism of action of fish oil in rheumatic diseases. Jpn. J. Pharmacol.79, 89-99.

Satoh K. 1978. Serum lipid peroxide in cerebrovascular disorders determined by a new colorimetric method. Clinica Chimica Acta. 20, 37-43.

Salvioli S, Sikora E, Cooper EL, Franceschi C. 2007. Curcumin in cell death processes: a challenge for CAM of age-related pathologies. Evidence-Based Complementary and Alternative Medicine 4, 181-190.

Selibert K, Zhang Y, Leahy K, Hauser S, Masferrer J, Perkins W, Lee L, Isakson P. 1994. Pharmacological and biochemical demonstration of the role of cyclooxygenase 2 in inflammation and pain. Proc. Natl. Acad. Sci., USA. 91, 12013.

Sevenian A, Davies KJA, Hochstein PA. 1985. Conservation of vitamin $\mathrm{C}$ by uric acid in blood. J. Free Rad. Biol. Med. 1, 117.

Singh GB, Singh S, Bani S, Gupta BD, Banerje SK. 1992. Anti-inflammatory activity of oleanolic acid in rats and mice. J. Pharm. Pharmacol. 44, 456-8.

Stepaniak JA, Gould KE, Sun D, Swanborg RH. 1995. A comparative study of experimental autoimmune encephalomyelitis in Lewis and DA rats. J. Immunol. 155, 2762-2769.

Tastekin N, Aydogdu N, Dokmeci D, Usta U, Birtane M, Erbas H, Ture M. 2007. Protective effects of L-carnitine and alpha-lipoic acid in rats with adjuvant arthritis. Pharmacol Res. 56, 303-10.

Van Ryn Y, Trummlitz G, Pairet M. 2000. COX-2 selectivity and inflammatory processes. Current Medicinal Chem. 7, 1145.

Venkatraman J, Meksawan K. 2002. Effect of dietary omega-3 and omega-6 lipids and vitamin $\mathrm{E}$ on chemokine levels in autoimmune-prone MRL/MpJ-lpr/ Ipr mice. J. Nutr. Biochem. 13, 479.

Watts RE. 1974. Determination of uric acid in blood and urine. Ann. Clin. Biochem. 11, 103-111.

Recibido: $1 / 12 / 10$ Aceptado: $22 / 2 / 11$ 